\title{
Treatment of Apatite Nepheline Ore Wasteenrichment Waste
}

\author{
Marina Valentinovna Maslova ${ }^{1}$, Lidiya Georgievna Gerasimova ${ }^{1} \&$ Anatoly Ivanovich Nikolaev ${ }^{1}$ \\ ${ }^{1}$ Institute of Chemistry and Technology of Rare Elements and Mineral Raw Materials, Kola Science Centre, \\ Russian Academy of Science, Russia \\ Correspondence: Maslova Marina Valentinovna, Institute of Chemistry KSC RAS, Akademgorodok 26a, Apatity, \\ 184200, the Murmansk region, Russian Federation. Tel: 7-921-288-4407. E-mail: maslova@chemy.kolasc.net.ru
}

Received: December 30, 2014

Accepted: January 3, 2014

Online Published: April 15, 2015

doi:10.5539/mas.v9n5p81

URL: http://dx.doi.org/10.5539/mas.v9n5p81

\begin{abstract}
The study demonstrated the efficiency of using the cascade reaction method applied to polymineral systems treatment, including technogenic waste of apatite nepheline ore. The conditions for minerals decomposition by sulphuric acid, content, and properties of forming solid phases have been researched. The sequence for carrying out production operations has been defined; the parameters and their operation modes were optimized. It is shown that by gradually increasing the sulphuric acid concentration and temperature the process can be carried out stepwise so that the products of one reaction participate in another reaction. This method provides complete use of initial mineral wastes and conversion of components in the form of wide range of useful products.
\end{abstract}

Keywords: mineral waste, nepheline, apatite, titanite, cascade reaction method

\section{Introduction}

The necessity for the rational use of mineral resources is caused by their scarcity and non-reproducibility. Under the conditions of highly intensive field exploitation, minor part of minable raw material is used. In recent years Mining, Minerals and Sustainable Development project has gained world support (MMSD Project, 2002). In respect to the use of mineral resources, this conception provides disposal of mining waste since under exploitation of natural resources is source of a considerable waste amount having adversely effect on the environment (Tiruta-Barna et al., 2007; McLellan et al., 2009). Waste deposits not only deprive useful area from economic circulation, but also represent the pollution sources of air, soil, underground, and surface water (Branwart, and Malmstrom, 2001; Stewart et al., 2003; Broadhurst \& Petrie, 2010; Young et al., 2000; Norgate et al., 2007). In this regard, the researches on waste disposal followed by obtaining the new types of inorganic materials are of current interest. Generally, mineral wastes are processed to recover the most valuable component thus not contributing to the complete waste disposal and slightly decreasing the environmental load.

The offered waste treatment processing method is based on the cascade reactions principle, consisting in the fact that a share of products resulting from serial-parallel reactions is a raw material for the subsequent technologic stages and resource for getting new products. It is significant that as far as all or the majority of mineral components being the result of chemical transformations form final products, non-waste and low-waste technologies can be considered. The new method can be applied for mining waste utilization. In order to justify it, it is necessary to conduct a particular complex of physical and chemical researches that includes the following stages:

- Determination of amount for each mineral component composing the test material;

- Definition of function for each mineral component;

- Selection of chemical reactions leading to final product formation;

- Study of kinetics and mechanism of final products formation;

- Selection of optimum components ratio for targeted synthesis of products with the tailored properties.

The possibility of cascade method application is shown in this work by the example of apatite nepheline ore wastes treatment (Kola peninsula, Russia). This waste is formed during ore flotation concentration with apatite and nepheline concentrate production. They are scarcely treated and, in the form of aqueous suspension, are sent to waste facilities. The new flow scheme of wastes disposal will allow producing a whole series of cheap products used in paint and construction materials industry, and sewage and processing waters purification of 
suspensions and pernicious contraries.

\section{Material and Method}

Nepheline wastes (fraction up to $100 \mu \mathrm{m}$ ) with composition (weight \%): nepheline $-30-35$, aegirine $-30-35$, titanite $-20-25$, apatite $-5-7$ were used in this study. Apatite and nepheline are concentrated in the fine fraction (up to $30 \mu \mathrm{m}$ ). The coarser fraction consists of titanite and aegerine. $10-40 \% \mathrm{H}_{2} \mathrm{SO}_{4}$ was used in decomposition processes.

The results of preliminary studies of individual concentrates were used to prepare a synthetic concentrate mixture similar to industrial wastes. The experiment was carried out in a glass reactor connected with a stirrer and a thermometer, under reflux. In the reactor, a calculated amount of sulphuric acid was initially placed and after that, the corresponding amount of concentrate was added. The obtained suspension was heated (if necessary) under stirring during $2-8 \mathrm{~h}$. The solid product was separated and both solid and liquid phases were analysed. The $\mathrm{pH}$ of solutions was measured with Orion $\mathrm{pH}$ meter 611 . The chemical composition of mineral waste was determined using AAS-300 atomic absorption spectrometer. Both the Initial and final materials were identified with Siemens D 5000 Powder X-ray diffractometer, with $\mathrm{Cu} K \alpha$ radiation. The final material was examined by SEM SEM-EDS a JEOL 3400.

\section{Results and Discussion}

The level of mineral waste decomposition was determined from different solubility of the minerals in sulphuric acid. Thereby, gradual leaching of components from minerals into liquid phase is taking place with their subsequent conversion into compounds, in which they individually or together with other compounds form final products. The alternation of chemical (solid phase interreacting with sulphuric acid) and physical (resulting suspension separation) reactions allows effecting process with preparation of intermediate and final product according to low waste technology.

Principal chemical reactions involved in the method are as follows:

$$
\begin{aligned}
& (\mathrm{NaK})_{2} \mathrm{Al}_{2} \mathrm{O}_{3} 2 \mathrm{SiO}_{2}+4 \mathrm{H}_{2} \mathrm{SO}_{4}=(\mathrm{NaK})_{2} \mathrm{SO}_{4}+\mathrm{Al}_{2}\left(\mathrm{SO}_{4}\right)_{3}+\mathrm{H}_{2} \mathrm{SiO}_{3}+3 \mathrm{H}_{2} \mathrm{O} \\
& \text { nepheline } \\
& \mathrm{Ca}_{5}\left(\mathrm{PO}_{4}\right)_{3} \mathrm{~F}+5 \mathrm{H}_{2} \mathrm{SO}_{4}=3 \mathrm{H}_{3} \mathrm{PO}_{4}+\mathrm{HF}+5 \mathrm{CaSO}_{4} \downarrow \\
& \text { apatite } \\
& \mathrm{Al}_{2}\left(\mathrm{SO}_{4}\right)_{3}+2 \mathrm{H}_{3} \mathrm{PO}_{4}=2 \mathrm{AlPO}_{4} \downarrow+3 \mathrm{H}_{2} \mathrm{SO}_{4} \\
& \mathrm{CaSiTiO}_{5}+2 \mathrm{H}_{2} \mathrm{SO}_{4}=\mathrm{TiOSO}_{4}+\mathrm{CaSO}_{4} \downarrow+\mathrm{SiO}_{2} \downarrow+2 \mathrm{H}_{2} \mathrm{O} \\
& \text { titanite } \\
& \mathrm{TiOSO}_{4}+\mathrm{H}_{3} \mathrm{PO}_{4}+\mathrm{H}_{2} \mathrm{O}=\mathrm{Ti}(\mathrm{OH})_{2}(\mathrm{HPO} 4) \downarrow+\mathrm{H}_{2} \mathrm{SO}_{4}
\end{aligned}
$$

Complexity and instability of system composition under study are the reason for particular challenges when developing technology. That is why an amount of each mineral component that composes waste under study was initially determined. Further interreacting kinetics of each mineral with selected sulphuric acid solution as well as mechanism of residues formation was studied and their optimum ratio for streamlined synthesis to produce tailored final products was defined.

\subsection{Stage I - Nepheline Dissolution}

First, the solubility studies involved nepheline as the most reactive component of the waste (Taylor and Eggleton, 2001; Tole et al., 1986; Jena et al., 2014; Hamilton et al., 2001). Nepheline was added to a sulphuric acid solution with a concentration of 50-150 g/l and consumption of 40 to $100 \%$ of the theoretically justified quantity in order to fix the acid-soluble components in sulphates.

Nepheline adding in solution of sulphuric acid was carried out for 15-20 minutes with the following stirring of reaction suspension for 1 hour without heating. When using sulphuric acid with a concentration of less than 100 $\mathrm{g} / 1 \mathrm{H}_{2} \mathrm{SO}_{4}$ leaching of main components proves to be incomplete and their content in liquid phase does not exceed $20 \mathrm{~g} / \mathrm{l}$ in aluminium and silicium when converted into oxides(in terms of oxides). Acid strengthening to $150 \mathrm{~g} / \mathrm{l}$ is accompanied by nearly complete leaching of mineral components. The crystallization process of aluminium sulphates and potassium alum takes place simultaneously. Under these conditions, silicium is prone to hard filterable colloid systems formation. At the consumption of sulphuric acid less than $85 \%$ the degree of 
nepheline decomposition dips down and suspension tendency to polymerization with producing of colloids increases. Increase in acid consumption more than $85 \%$ of stoichiometry contributes to increase in transition degree of main components into solution to $90 \%$, but resultant acid solutions are unusable (Figure 1), for example, as coagulum flocculants, since low $\mathrm{pH}$ of such solutions may lead to acidification of purifying water. According to findings, optimum conditions for nepheline decomposition are as follows: $\mathrm{H}_{2} \mathrm{SO}_{4}$ concentration $100 \mathrm{~g} / \mathrm{l}$ at the rate of $85 \%$ of stoichiometric rate (Table 1 ).

Table 1. Nepheline dissolution by sulphuric acid

\begin{tabular}{|c|c|c|c|c|c|}
\hline \multirow[t]{2}{*}{$\begin{array}{l}\mathrm{H}_{2} \mathrm{SO}_{4}, \quad \text { initial } \\
\text { concentration, } \mathrm{g} \cdot \mathrm{l}^{-1}\end{array}$} & \multirow{2}{*}{$\begin{array}{ll}\mathrm{H}_{2} \mathrm{SO}_{4}, \quad \% & \text { of } \\
\text { stoichiometric } & \\
\text { value } & \end{array}$} & \multirow{2}{*}{$\begin{array}{l}\text { components } \\
\text { phase, } \mathrm{g} \cdot \mathrm{l}^{-1} \\
\mathrm{Al}_{2} \mathrm{O}_{3}\end{array}$} & \multirow{2}{*}{$\begin{array}{l}\text { in liquid } \\
\mathrm{SiO}_{2}\end{array}$} & \multicolumn{2}{|c|}{ release to solution, $\%$} \\
\hline & & & & $\mathrm{Al}_{2} \mathrm{O}_{3}$ & $\mathrm{SiO}_{2}$ \\
\hline \multirow[t]{3}{*}{50} & 50 & 11.83 & 21.25 & 50.24 & 51.13 \\
\hline & 85 & 10.92 & 18.82 & 79.17 & 76.85 \\
\hline & 100 & 10.12 & 17.24 & 84.41 & 82.56 \\
\hline \multirow[t]{3}{*}{100} & 50 & 29.54 & 50.35 & 62.32 & 60.52 \\
\hline & 85 & 24.96 & 44.27 & 89.71 & 90.43 \\
\hline & 100 & 21.85 & 39.45 & 92.24 & 94.75 \\
\hline \multirow[t]{3}{*}{150} & 50 & 5216 & 88.26 & 73.43 & 70.77 \\
\hline & 85 & 33.41 & 56.34 & 79.82 & 76.62 \\
\hline & 100 & \multicolumn{4}{|c|}{ gelatinization } \\
\hline
\end{tabular}

As the nepheline components pass to solution, the suspension $\mathrm{pH}$ increases to 1.8-2.1. After stirring for 30-60 min, the suspension $\mathrm{pH}$ grows to 2.2-2.4. The undecomposed nepheline particles are separated by filtration. The solution represents a stable colloid system containing, g/l: $\mathrm{Al}_{2} \mathrm{O}_{3}-20-30, \mathrm{SiO}_{2}-40-50, \mathrm{Na}_{2} \mathrm{O}-10-15, \mathrm{~K}_{2} \mathrm{O}-5-10$ (Berkowitz et al., 2005; Otterstedt et al., 1987; Matijevis et al., 1971). The level of nepheline decomposition was determined from the leaching level of the most acid-resistant aluminium and silica oxides. Under optimal conditions, the decomposition achieves 90-95\%. The obtained colloid solutions can be used for thickening of fine suspensions and for treatment of industrial wastewater (Gao et al., 2002; Velyaev et al., 2011).

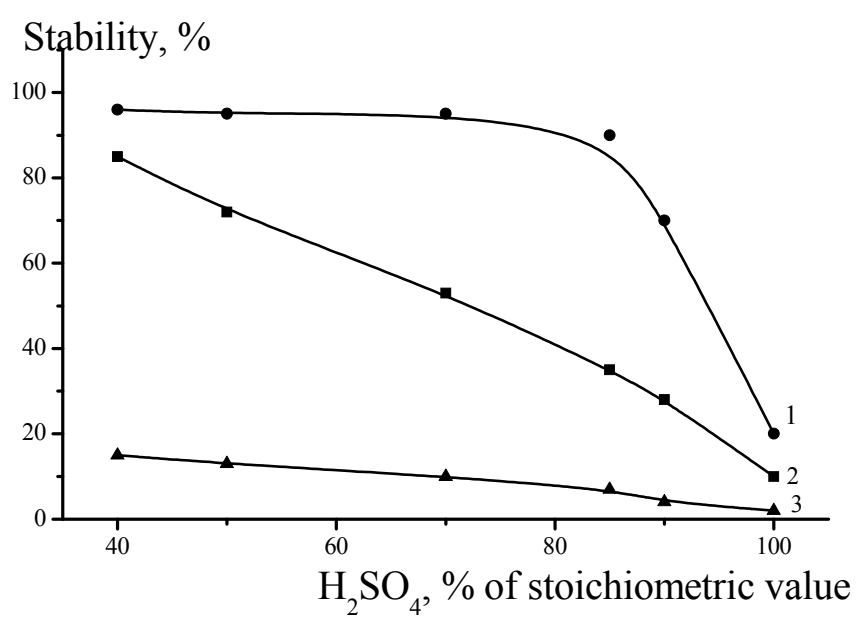

Figure 1. Stability to dilution of solutions obtained through nepheline dissolution in sulphuric acid with a concentration of (g/l) 1-50, 2-100, 3-150

\subsection{Stage II - Apatite Dissolution}

The second stage is interaction of apatite with sulphuric acid solution. The process of sulphuric acid decomposition of apatite results in phosphoric acid with a concentration of $28-50 \%$ in $\mathrm{P}_{2} \mathrm{O}_{5}$ and in calcium sulphate in the form of gypsum (Evenchik \& Brodskii, 1987; Pozin, 1974).

Sulphuric acid concentration impact and rate have been studied, as well as process time impact on apatite decomposition degree and structural features of calcium phase. For this purpose when stirring concentrated 
sulphuric acid in amount of $110 \%$ of its stoichiometric amount necessary for calcium banding in the form of gypsum was slowly added ( $\sim 30 \mathrm{~min})$ into aqueous suspension of apatite. Resulting concentration of $\mathrm{H}_{2} \mathrm{SO}_{4}$ in liquid phase is $10-40 \%$. Due to heat release, the suspension temperature increases to $75-80{ }^{\circ} \mathrm{C}$. The the process lasts 2-6h. The process duration and temperature affect the recovery of fluorine, evolving in the form of hydrofluosilicic acid with gas-vapour phase $\left(\mathrm{SiO}_{2}+6 \mathrm{HF} \rightarrow \mathrm{H}_{2} \mathrm{SiF}_{6}+2 \mathrm{H}_{2} \mathrm{O}\right)$ and decreasing medium aggressivity, depends on hold-up time and temperature. Resulting gypsum is separated by filtrating and washed with water at $\mathrm{S}: \mathrm{L}=1: 3$. Apatite decomposition data is shown in Table 2.

Table 2. Regimes of apatite dissolution affecting the composition of liquid and solid phases

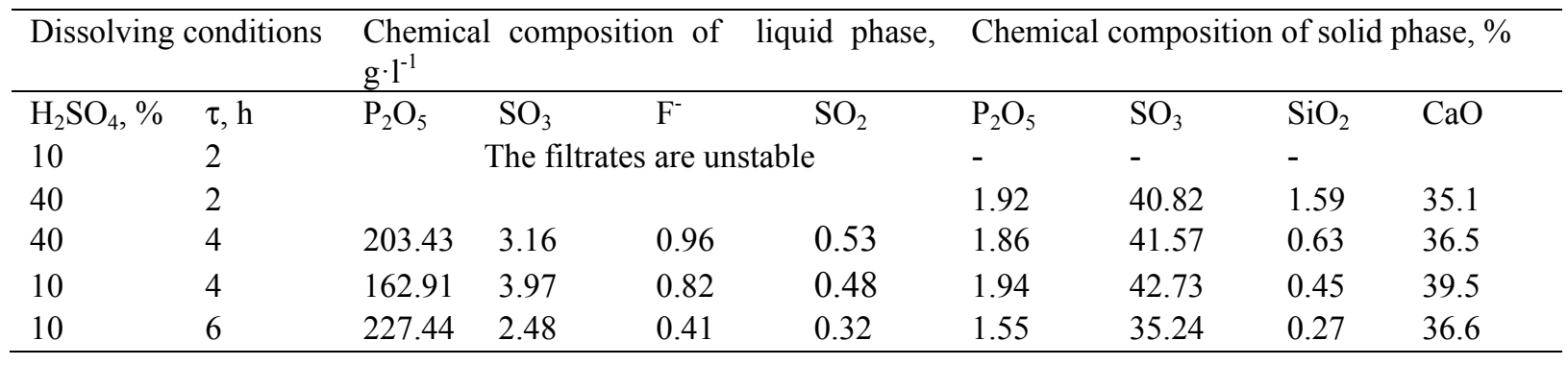

Sulphuric suspension holding for 2 hours at a temperature of $80^{\circ} \mathrm{C}$ regardless of $\mathrm{H}_{2} \mathrm{SO}_{4}$ concentration is insufficient for complete solid phase precipitation. With increase of reacting mass holding time to $4 \mathrm{~h}$ the system is close to equilibrium and calcium precipitates almost completely. The higher sulphuric acid concentration, the more phosphorus content is in the liquid phase. In the case of process time of $6 \mathrm{~h}$, ultimate recovery of phosphorus from apatite is reached (Figure 2).

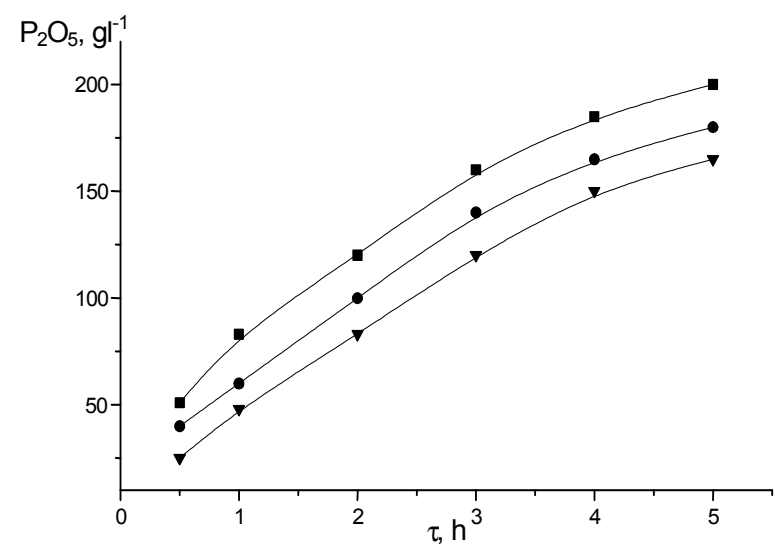

Figure 2. The effect of sulphuric acid concentration on $\mathrm{P}_{2} \mathrm{O}_{5}$ extraction from apatite.

$\mathrm{H}_{2} \mathrm{SO}_{4} \%(\boldsymbol{\Delta}-10, \bullet-20, \mathbf{\square}-40)$.

XRD analysis shows that main phase in all samples is gypsum - CaSO4.2H2O, according to crystal optical analysis its particles is of needle prismatic form from $4-28 \mu \mathrm{m}$ to 5-64 $\mu \mathrm{m}$, are prone to aggregation (Figure $6 \mathrm{c}$ ). Impurity phase is anhydrite, the amount of which increases with increase in sulphuric acid concentration.

The studies has proved that sulphuric acid concentration increase for more than $20 \%$ in $\mathrm{H} 2 \mathrm{SO} 4$ is unfeasible since during real wastes processing titanite will be composed together with apatite (Figure 3). For that reason the optimum conditions for apatite dissolution are as follows: 15-20\% H2SO4, temperature 80o C; reaction time 6 h. Gypsum precipitation is well aggregated, low-level in relation to the mother solution. 


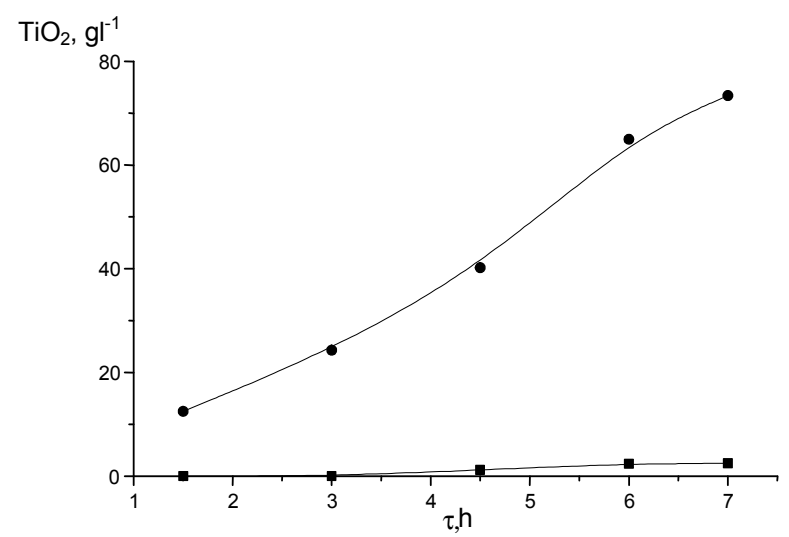

Figure 3. Titanium (IV) leaching from titanite during its dissolution ( $\left.\mathrm{T}_{\text {boil }}\right)$ by $\mathrm{H}_{2} \mathrm{SO}_{4}, \%(\mathbf{m}-15, \bullet-40)$

\subsection{Stage III - Titanite Dissolution}

Choosing conditions for titanite dissolution is based on the necessity of titanium (IV) transition into liquid phase. Previously it had been established that this process occurs under rigid conditions: sulphuric acid high concentration - 1000-1700 g/ $1 \mathrm{H}_{2} \mathrm{SO}_{4}$, elevated temperature - 140-200 ${ }^{\circ} \mathrm{C}$ (Motov and Maximova, 1983). Then the concentration of sulphuric acid is about $350 \mathrm{~g} / \mathrm{l}, \mathrm{H}_{2} \mathrm{SO}_{4}$ titanium (IV) in liquid is unstable and precipitates in the form of titanium hydroxide. Herewith, mineral decomposition degree does not exceed $50 \%$ (Motov \& Maksimova, 1983).

For the research, 400-600 g/ $1 \mathrm{H}_{2} \mathrm{SO}_{4}$ was chosen. This concentration provides high stability of titanium (IV) in liquid phase and leads to preparation of all-purpose titanium-containing precursor (as solution), which acts as a basis for subsequent syntheses of various titanium-containing products (Lazareva et al., 2006).

The test object was fine-grained titanite $\left(\mathrm{TiO}_{2}-35-37 \%\right)$. The dissolution process was carried out at $105-115^{\circ} \mathrm{C}$ during 7-8 $\mathrm{h}$, at a ratio of titanite and acid of $\mathrm{T}: \mathrm{V}_{\mathrm{L}}=1: 3$. At that point leaching of titanite components takes place into liquid sulphuric acid phase with the later formation of reaction solid products - calcium sulphate and amorphous silica. Owing to high solubility, titanium (IV) is concentrated in liquid phase.

Figure 4 shows the relationship between titanium extraction from titanite and the sulphuric acid concentration. Initially, the process occurs at the surface of fine-grained mineral particles with components leaching in liquid phase gradually forming solid products.

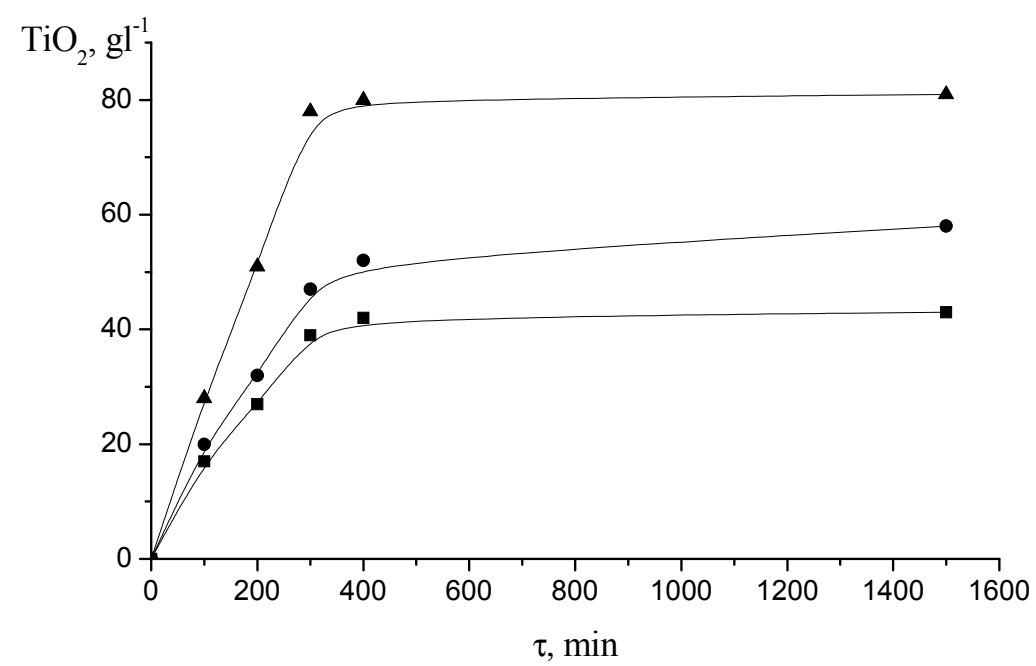

Figure 4. The effect of sulphuric acid concentration on the rate of titanium leaching to the liquid phase. $\mathrm{H}_{2} \mathrm{SO}_{4}$, $\mathrm{g} / \mathrm{l}(\mathbf{\Delta}-400, \bullet-500, \mathbf{m}-600)$ 
Temperature rise and concentration of $\mathrm{H}_{2} \mathrm{SO}_{4}$ have a positive effect on reaction speed. This stage time is about 60 minutes. According to XRD analysis, there is mainly titanite in solid phase and anhydrite in fewer amounts. With increase in reaction products in reaction mass, the process slows down. According to SEM data, products are formed in the form of individual phases, and forms porous shell at the surface of undecomposed sphene particles as well (Figure 5).

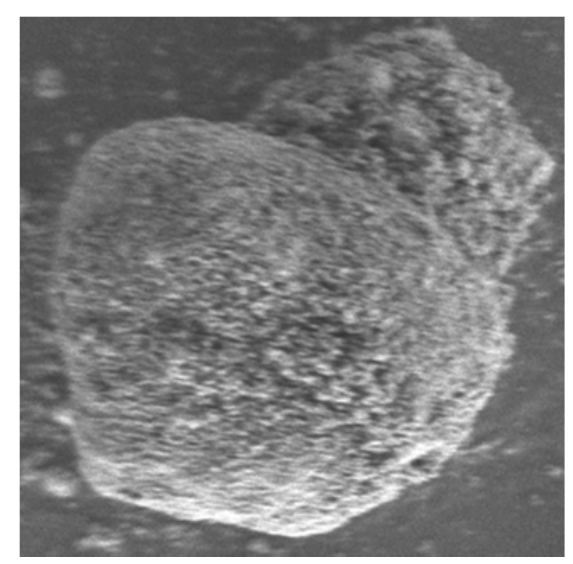

Figure 5. SEM image of titanite particle after $60 \mathrm{~min}$ of mineral dissolution

The reaction rate becomes slower with increasing amount of the reaction products due to diffusion of the acid through the layer of newly-formed phases.

Approximately, in $5 \mathrm{~h}$ decomposition rate is so low that one can consider pseudoequilibrium state of the system that can be tilted by external influence only. The optimal concentration of sulphuric acid, permitting to leach the maximum of titanium, should be considered to be $600 \mathrm{~g} / 1 \mathrm{H}_{2} \mathrm{SO}_{4}$.

\section{The Flow Sheet and Target Products}

Flow chart of mineral wastes treatment with final products obtaining is shown in Figure 6. 


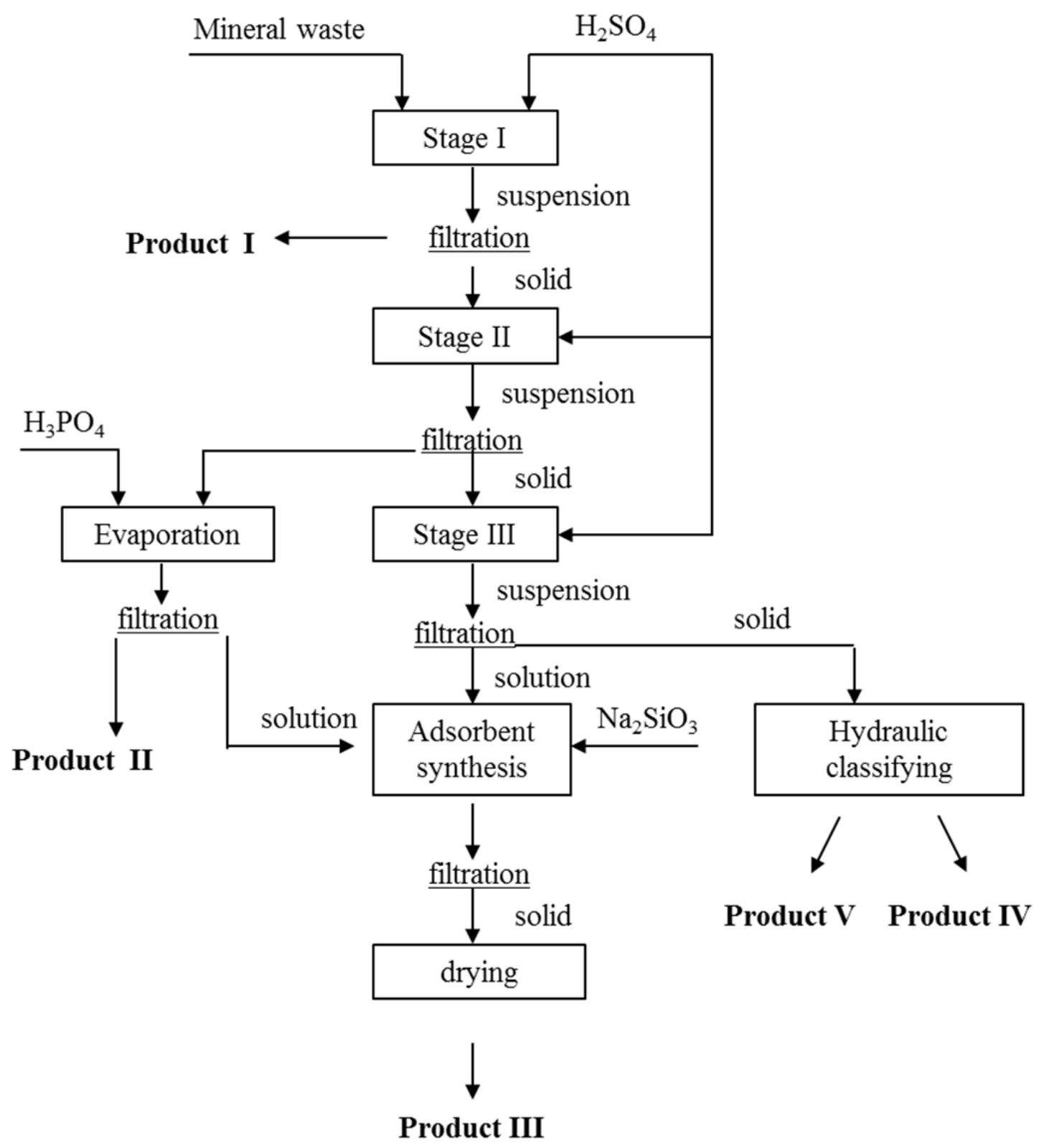

Figure 6. Schematic flow chart of apatite nepheline mineral waste utilization

The process proceeds in a periodic mode. At the first stage of decomposition wastes composed of minerals mixture (Figure 7a) are treated with $100 \mathrm{~g} / \mathrm{H} \mathrm{H}_{2} \mathrm{SO}_{4}$ solution at the solid-liquid stage ratio of $\mathrm{S}: \mathrm{L}=1: 6$. 


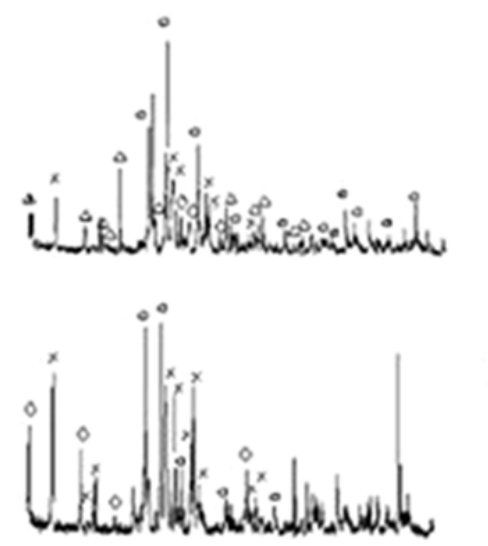

a

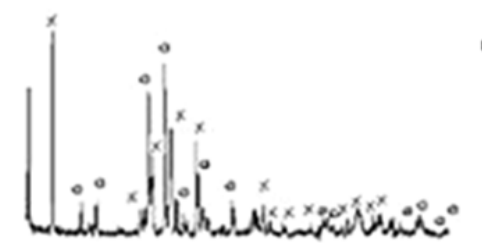

b
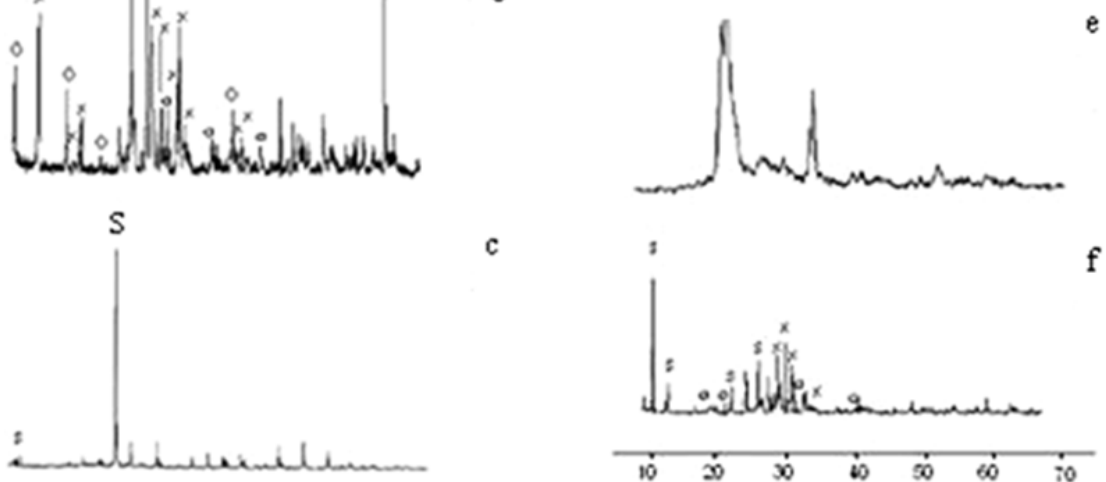

c

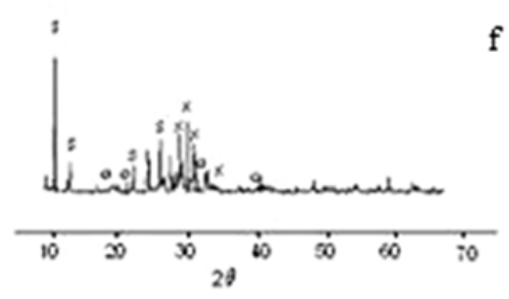

$\mathrm{o}$ - titanite; $\Delta$ - nepheline; $\diamond$ - apatite; $\mathrm{x}$ - aegirine; $\mathrm{s}$ - CaSO4

Figure 7. XRD powder patterns for (a)-apatite nepheline mineral waste, (b)-residue after nepheline dissolving, (c)- gypsum, (d)- residue after apatite dissolving, (e)-titanium phosphate, (f)- the residue after third stage

Under the chosen conditions the nepheline decomposition degree is about $90 \%$. When $\mathrm{pH}$ reaches $2.2-2.4$, the solid phase is separated by filtrating. The liquid phase is an aluminium and silicium colloid solution, which is watered to $10 \mathrm{~g} \cdot \mathrm{l}^{-1}$ of $\mathrm{SiO}_{2}$ in order to increase the aggregative stability. The efficiency of using this colloid solution as a coagulum flocculants (Product I) is shown in Table 3.

Table 3. Purification properties of alumosilicium coagulant

\begin{tabular}{llll}
\hline Impurities & Before purification, $\mathrm{mg} \cdot \mathrm{l}^{-1}$ & After purification, $\mathrm{mg} \cdot \mathrm{l}^{-1}$ & $\begin{array}{c}\text { Purification } \\
\text { efficiency, } \%\end{array}$ \\
\hline Oil & 0.53 & 0.27 & 49.0 \\
Suspensions & 87.60 & 14.20 & 83.8 \\
Nitrate & 1.41 & 1.00 & 29.1 \\
Sulphate & 69.81 & 63.62 & 8.9 \\
Chloride & 17.20 & 14.61 & 15.1 \\
Phosphate & 2.93 & 0.89 & 69.6 \\
Ferrum & 3.50 & 0.99 & 71.7 \\
\hline
\end{tabular}

Represented data allows recommending aluminosilicic coagulum flocculants for cleaning industrial waste of suspensions and oil (Zouboulis and Tzoupanos, 2009; Zakharov, et al., 1996; Morgunov, et al., 2006) After the nepheline dissolution (Figure $7 \mathrm{~b}$ ), the solid phase is loaded into a $15 \% \cdot \mathrm{H}_{2} \mathrm{SO}_{4}$ solution. at $\mathrm{S}: \mathrm{L}=1: 1$. The suspension is heated to $80^{\circ} \mathrm{C}$ and stirred for $6 \mathrm{~h}$. In the process of heating decomposition of the residual quantity of nepheline and apatite with the formation of phosphoric solution containing aluminium and silicium takes place. Calcium sulphate is crystallized in the form of gypsum and settles out (Figure 7c), which is separated from the solution by filtrating. Orthophosphoric acid is added into the solution to precipitate aluminium and silica gel phosphates. Resultant residues wash off mother liquor and heat-treated (Product II). By varying the treatment regimes it is possible to obtain products different functional properties. (Table 4) (Kalendova, 2003; Yeh \& Chang, 2008; Tolmachev, 1998). 
Table 4. The effect of treatment regime on the functional properties of Product II

\begin{tabular}{|c|c|c|}
\hline Heat up ${ }^{\circ} \mathrm{C}$ & Chemical composition & Areas of application \\
\hline $40-50$ & $\begin{array}{l}\text { Acidicaluminiumhydrophosphate, } \\
\text { amorphous silica }\end{array}$ & $\begin{array}{l}\text { Anticorrosion paint } \\
\text { primers, underpaint putty }\end{array}$ \\
\hline $90-120$ & $\begin{array}{l}\text { Basic aluminiumhydrophosphate, } \\
\text { amorphous silica }\end{array}$ & $\begin{array}{l}\text { Water-based paints (dull), } \\
\text { coupling agents }\end{array}$ \\
\hline $400-550$ & aluminium phosphate & $\begin{array}{l}\text { Water- and organic-based } \\
\text { paints (gloss) }\end{array}$ \\
\hline
\end{tabular}

The solid residue after apatite separation, (Figure 7d) is treated with sulphuric acid with a concentration of $600 \mathrm{~g} / 1 \mathrm{H}_{2} \mathrm{SO}_{4}$ at a solid-liquid ratio of $\mathrm{S}: \mathrm{L}=1: 3$. The reaction mass is heated to boiling temperature, held for $7 \mathrm{~h}$ and the suspension is filtered. Sulphuric filtrate with a titanium (IV) concentration, when converted into $\mathrm{TiO}_{2}$ $-80-100 \mathrm{~g} / \mathrm{l}$ and $420-470 \mathrm{~g} \cdot \mathrm{l}^{-1} \mathrm{H}_{2} \mathrm{SO}_{4}$, is used for synthesis of titanium-containing ion-exchanger material (Product III) (Bortun et al., 1997; Clearfield, 1995; Nilchi et al., 2004).

For this purpose the solution was heated up to $65-75{ }^{\circ} \mathrm{C}$ and the corresponding amount of silica agent (molar ratio of $\left.\mathrm{TiO}_{2}: \mathrm{SiO}_{2}=1: 0.15-0.2\right)$ was added to it. After stirring of solution for $30 \mathrm{~min}$, phosphoric acid $\left(\mathrm{TiO}_{2}: \mathrm{P}_{2} \mathrm{O}_{5}=1: 0.5-2\right)$ is added. The low solubility of titanium and silicium phosphates favours the emergence of seeds promoting the formation of composite solid (Reaction 5). Evaporated filtrate after the stage of titanite dissolution is used as a phosphoric reagent. The suspension was agitated for $6 \mathrm{~h}$, the solid then filtered and washed with water (till $\mathrm{pH} 3.0-3.2$ ). The final solid was dried initially on air and then at $70^{\circ} \mathrm{C}$. Precipitation degree of titanium (IV) when producing titanium phosphate is $95-99 \%$. The final silica titanium phosphate composite with formula $\mathrm{Ti}(\mathrm{OH})_{2(1-\mathrm{x})}\left(\mathrm{HPO}_{4}\right)_{\mathrm{x}} \cdot \mathrm{ySiO}_{2} \cdot \mathrm{nH}_{2} \mathrm{O}$ can be used as an ion-exchanger (Figure 6e) ((Maslova et al., 2008). The silicium component facilitates pelletizing of the material. The synthesized material has good sorption affinity towards mono- and polyvalent metal cations (Figure 8).

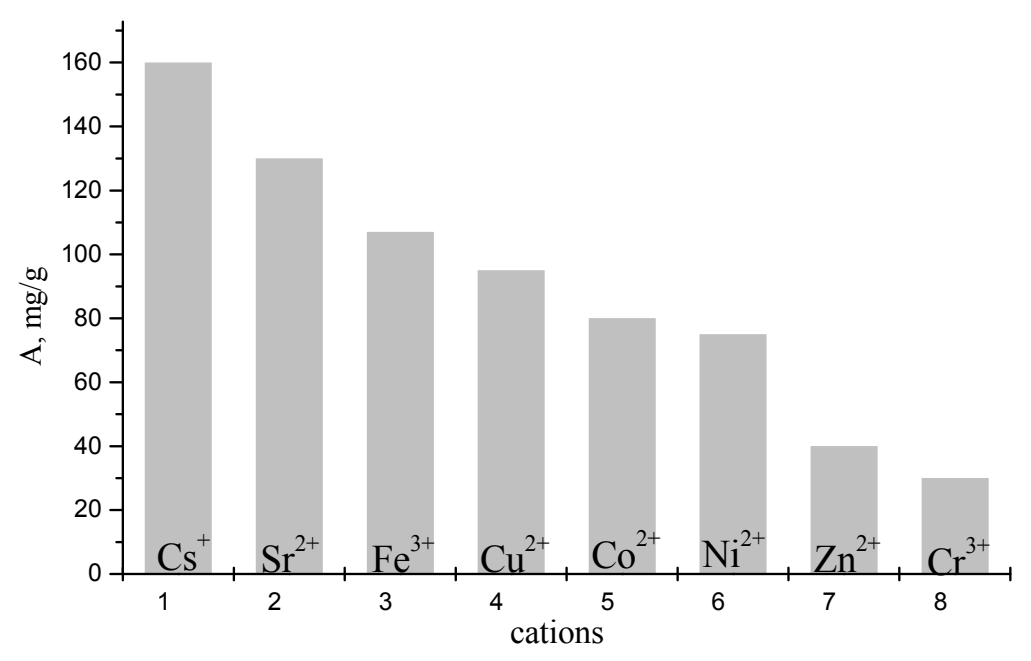

Figure 8. Sorption affinity (A) of some cations by titanium phosphate composition

Residue from the titanite decomposition (Figure 7f) is divided into synthetic and mineral factions by means of hydraulic classification. The synthetic fraction, collected in catchers, includes calcium sulphate and amorphous silica. The residue is heat treated at $300^{\circ} \mathrm{C}$. The resulting Product IV is a white or ecru powder, which can be used as component of dry construction mixtures (Olmez \& Erden, 1989; Singh \& Garg, 2000; Singh, 1988; Singh \& Garg, 1992). The mineral part, mainly consisting of aegerite (Product V), is used in the production of weatherproof fillers of paint and construction materials (Table 5). 
Table 5. Characteristics of the products obtained from mineral waste

\begin{tabular}{|c|c|c|}
\hline Product & Components & Field of use \\
\hline Product I & $\begin{array}{l}\text { Colloidal solution of aluminium and } \\
\text { silicium-a coagulating-flocculating agent }\end{array}$ & $\begin{array}{l}\text { Thickening of suspensions with a finely divided } \\
\text { solid phase. Water purification from oil, } \\
\text { suspensions, iron, etc. }\end{array}$ \\
\hline Product II & Acid aluminium phosphate, silica gel & $\begin{array}{l}\text { Anticorrosion compounds on the organic and } \\
\text { water bases }\end{array}$ \\
\hline Product III & $\begin{array}{l}\text { Titanium hydrophosphate or its composite } \\
\text { with silica gel }\end{array}$ & Sorbent purification of toxic liquid effluents \\
\hline Product IV & $\begin{array}{l}\text { Calcium sulphate, amorphous silica, } \\
\text { titanium dioxide }\end{array}$ & Dry building composites for whitewashing \\
\hline Product V & Sphene and aegirite concentrates & $\begin{array}{l}\text { In the production of pigments, weather-resistant } \\
\text { paints and paint primers }\end{array}$ \\
\hline
\end{tabular}

\section{Conclusions}

By using the data of mineral composition of polymineral apatite-nepheline ore dressing wastes, there has been developed a method of their recovery, yielding synthetic and mineral products. This involved researching of the kinetics of mineral dissolution in sulphuric acid and mechanism of phase formation in the resulting system. With regard for different solubility of nepheline, apatite, titanite and egirine in acid media, the sequence of mineral separation was determined. There have been determined the parameters ensuring the process completeness. The composition and characteristics of solid and liquid phases obtained during the mineral dissolution have been studied, which permitted to use them directly as precursors in synthesis of such useful products as anticorrosion pigments and binding materials, water and organic paint fillers, and sorbents of the ion-exchange type. Processing of polymineral (not individual) wastes in sulphuric acid has shown that the main process parameters are easily adjustable. On the basis of a physical-chemical study, there has been developed a technology for polymineral wastes processing which meets the environmental requirements.

\section{References}

Berkowitz, J., Anderson, M. A., \& Graham, R. C. (2005). Laboratory investigation of aluminiumsolubility and solid phase properties folloing alum treatment of lake water. Water Research, 39(16), 3918-3928. http://dx.doi.org/10.1016/j.watres.2005.06.025

Bortun, A. I., Bortun, L. N., \& Clearfield, A. (1997). Synthesis and characterization of ion exchange properties of spherically granulated titanium phosphate. Solvent extraction and ion exchange, 15(3), 515-532. http://dx.doi.org/10.1080/07366299708934491

Branwart, S. A., \& Malmstrom, M. E. (2001). Hydrochemical modeling for preliminary assessment of mine water pollution. J. Geochemical Exploration, 74, 73-97. http://dx.doi.org/10.1016/S0375-6742(01)00176-5

Broadhurst, J. L., \& Petrie, J. G. (2010). Ranking and scoring potential environmental risks from solid mineral wastes. Minerals Engineering, 23, 182-191. http://dx.doi.org/10.1016/j.mineng.2009.09.008

Clearfield, A. (1995). Inorganic ion exchangers: A technology ripe for development. Ind. Engineering Chemistry Research, 34, 2865-2872. http://dx.doi.org/10.1021/ie00047a040

Evenchik, E. L., \& Brodsky, A. A. (1987). Technology of phosphate and complex fertilizers. Moscow, Nauka.

Gao, B. Y., Hahn, N. N., \& Hoffmann, E. (2002). Evaluation of aluminium-silicate polymer composite as a coagulant for water treatment. Water Research, 36(14), 3573-3581. http://dx.doi.org/10.1016/S0043-1354(02)00054-4

Hamilton, J. P., Brantley, S. L., Pantano, C. G., Criscenti, L. J., \& Kubicki, J. D. (2001). Dissolution of nepheline, Jadeite and albite glasses: Toward better models for aluminosolicate dissolution. Geochimica et Cosmochimica Acta, 65(21), 3683-3702. http://dx.doi.org/10.1016/S0016-7037(01)00724-4

Jena, S. K., Dhawana, N., Rao, D. S., Misra, P. K., Mishra, B. K., \& Das, B. (2014). Studies on extraction of potassium values from nepheline syenite. International Journal of Mineral Processing, 133, 13-22. http://dx.doi.org/10.1016/j.minpro.2014.09.006

Kalendova, A. (2003). Comparison of the anticorrosion efficiencies of pigments based on condensed phosphates and polyphosphosilicates. Anti-Corrosion Methods and Materials, 50(2), 82-90. 
http://dx.doi.org/10.1108/00035590310463957

Lazareva, I. V., Gerasimova, L. G., Okhrimenko, R. F., \& Maslova, M. V. (2006). Reaction of shene with sulphuric acid solutions. Rus. J. Applied Chemistry, 79(1), 16-19. http://dx.doi.org/10.1134/S1070427206010046

Maslova, M. V., Rusanova, D., Naidenov, V., Antzutkin, O. N., \& Gerasimova, L. G. (2008). Synthesis, characterization and sorption properties of amorphous titanium phosphate and silica-modified titanium phosphates. Inorganic Chemistry, 47(23), 11351-11360. http://dx.doi.org/10.1021/ic801274z

Matijevis, E., Mangrative, F. J., \& Cassel, E. A. (1971). Stability of colloidal silica IV. The silica-alumina system. J. Colloid Interface Sci., 35(4), 560-568. http://dx.doi.org/10.1016/0021-9797(71)90214-1

McLellan, B. C., Gorden, G. D., Giurco, D., \& Green, S. (2009). Incorporating sustainable development in the design of mineral processing. Review and analysis of current approaches. J. Cleaner Production, 17, 1414-1425. http://dx.doi.org/10.1016/j.jclepro.2009.06.003

Morgunov, A. F., Kruchinina, N. E., Timasheva, N. E., \& Morgunov, P. A. (2006). Colloid-chemical regularities of water purification using an alumino-silicate flocculating-coagulating agent. Izvestiya VUZ. Chemistry and chemical technology, 49(4), 20-24.

Motov, D. L., \& Maksimova, G. K. (1983). Sphene and its chemical processing for titanium pigments and fillers. Leningrad, Nauka

Nilchi, A., Maragheh, M. G., Khanchi, A., Farajzadeh, M. A., \& Aghaei, A. A. (2004). Synthesis and ion-exchange properties of crystalline titanium and zirconium phosphates. J.Radioanal. Nuclear Chem., 261(2), 393-400. http://dx.doi.org/10.1023/B:JRNC.0000034876.90837.fa

Norgate, T. E, Jahanshahi, S., \& Rankin, W. J. (2007). Assessing the environmental impact of metal production processes. J. Cleaner Production, 15(8-9), 838-848. http://dx.doi.org/10.1016/j.jclepro.2006.06.018

Olmez, H., \& Erden, E. (1989). The effect of phosphogypsum on the setting and mechanical properties of Portland cement and trass cement. Cement and Concrete Research, 19, 377-384. http://dx.doi.org/10.1016/0008-8846(89)90027-6

Otterstedt, J. E. A., Ghuzel, M., \& Sterte, J. P. (1987). Colloidal components in solutions of alkali silicates. J. Colloid Interface Sci., 115(1), 95-103. http://dx.doi.org/10.1016/0021-9797(87)90012-9

Pozin, M. E. (1974). Technology of mineral salts. Part 1. Chemistry, Leningrad.

Singh, M. (1988). Utilization of by-product phosphogypsum for building materials. Building Research Note 9. CBRI Publication, Roorkee, India.

Singh, M., \& Garg, M. (1992). Investigation of durable gypsum binder for building materials. Construction Building Materials, 6, 52-56. http://dx.doi.org/10.1016/0950-0618(92)90030-3

Singh, M., \& Garg, M. (2000). Making of anhydrite cement from waste gypsum. Cement and Concrete Research, 30, 571-577. http://dx.doi.org/10.1016/S0008-8846(00)00209-X

Stewart, M., Basson, L., \& Petrie, J. G. (2003). Evolutionary design for environment in minerals processing. Process Safety and Environmental Protection, 81, 341-51. http://dx.doi.org/10.1205/095758203770224379

Taylor, G., \& Eggleton, R. A. (2001). Regolith Geology and Geomorphology. Wiley, London.

Tiruta-Barna, L., Benetto, E., \& Perrodin, Y. (2007). Environmental impact and risk assessment of mineral wastes reuse strategies: Review and critical analysis of approaches and applications. Resources, Conservation and Recycling, 50, 351-379. http://dx.doi.org/10.1016/j.resconrec.2007.01.009

Tole, M. P., Lasagaa, A. C., Pantanoa, C., \& Whitea, W. B. (1986). The kinetics of dissolution of nepheline $\begin{array}{lllll}\left(\mathrm{NaAlSiO}_{4}\right) . \quad \text { Geochimica et } & \text { Cosmochimica }\end{array}$ http://dx.doi.org/10.1016/0016-7037(86)90191-2

Tolmachev, I. A. (1998). Anticorrosive water-based paints. Rus. J. Paint-and-varnish materials and their application, 1, 23-28.

Velyaev, Yu. O., Zakharov, V. I., \& Mayorov, D. V. (2011). Improving the technology of producing an alumosilicon coagulating-flocculating agent from nepheline. J.Physics and Chemistry of Glass, 37(5), 129-135.

Yeh, J. M., \& Chang, K. C. (2008). Polymer/layered silicate nanocomposite anticorrosive coating. J. Industrial 
and Engineering Chemistry, 14(3), 275-291. http://dx.doi.org/10.1016/j.jiec.2008.01.011

Young, D., Scharp, R., \& Cabezas, H. (2009). The waste reduction (WAR) algorithm: Environmental impacts, energy consumption, and engineering economics. Waste Management, 20(8), 605-615. http://dx.doi.org/10.1016/S0956-053X(00)00047-7

Zakharov, V. I., Matveev, V. A., \& Maiorov, D. V. (1996). Effect of process parameters of acid decomposition of nepheline on the filterability of silica sediments. Russ. J. Applied Chemistry, 69(3), 322-326.

Zouboulis, A. I., \& Tzoupanos, N. D. (2009). Polyaluminium silicate chloride - a systematic study for the preparation and application of an efficient coagulant for water or wastewater treatment. J. Hazardous Materials, 162(2-3), 1379-1389. http://dx.doi.org/10.1016/j.jhazmat.2008.06.019

\section{Copyrights}

Copyright for this article is retained by the author(s), with first publication rights granted to the journal.

This is an open-access article distributed under the terms and conditions of the Creative Commons Attribution license (http://creativecommons.org/licenses/by/3.0/). 